\title{
RANDOMIZED CONTROLLED CLINICAL TRIAL ON TWO PERINEAL TRAUMA SUTURE TECHNIQUES IN NORMAL DELIVERY
}

Sandra Ferreira Silva de Almeida ${ }^{1}$ Maria Luiza Gonzalez Riesco ${ }^{2}$

Almeida SFS, Riesco MLG. Randomized controlled clinical trial on two perineal trauma suture techniques in normal delivery. Rev Latino-am Enfermagem 2008 março-abril; 16(2):272-9.

The aim was to compare healing and perineal pain with the use of continuous and interrupted suture techniques in women after normal delivery. A randomized controlled trial was carried out at a hospital birth center in Itapecirica da Serra, Sao Paulo, Brazil. A total of 61 women participated with episiotomy or second degree perineal tear, allocated in two groups according to the continuous $(n=31)$ or interrupted $(n=30)$ suture techniques. The main outcomes evaluated were edema, ecchymosis, hyperemia, secretion, dehiscence, fibrosis, frequency and degree of pain (evaluated by numerical scale from 1 to 10). Data were collected during hospitalization and after discharge (four and 41 days after birth). Healing occurred by first intention in 100\% of cases in both suture techniques. There were no statistically significant differences for the occurrence of morbidities, except for perineal pain due to palpation at four days after delivery, which was more frequent among women with interrupted suture.

DESCRIPTORS: delivery; perineum; pain; suture techniques; obstetrical nursing; clinical trials

\section{ENSAYO ALEATORIO CLÍNICO CONTROLADO PARA DOS TÉCNICAS DE SUTURA PERINEAL EN PARTO NORMAL}

El objetivo fue comparar la cicatrización y el dolor perineal utilizando técnicas de sutura continua y separada, en mujeres que realizaron parto normal. El estudio fue controlado aleatorio, realizado en un centro para parto normal en Itapecerica de la Sierra, Sao Paulo. Participaron 61 mujeres con episiotomía o desgarro perineal de segundo grado, distribuidas en dos grupos (sutura continua $n=31$ y sutura separada $n=30$ ). Las principales medidas evaluadas fueron edema, equimosis, hiperemia, secreción, dehiscencia de herida, fibrosis, frecuencia y magnitud del dolor (evaluada por escala numérica de 1 a 10). Los datos fueron recolectados durante la hospitalización y después del alta (de 4 a 41 días post-parto). La cicatrización fue por primera intención en 100\% de los casos, para las dos técnicas de sutura. No se encontró diferencia estadísticamente significativa en los casos de morbilidad, con excepción del dolor perineal a la palpación al cuarto día post-parto, el que fue más frecuente en mujeres con sutura separada.

DESCRIPTORES: parto; perineo; dolor; técnicas de sutura; enfermería obstétrica; ensayos clínicos

\section{ENSAIO CLÍNICO CONTROLADO ALEATÓRIO SOBRE DUAS TÉCNICAS DE SUTURA DO TRAUMA PERINEAL NO PARTO NORMAL}

O objetivo foi comparar a cicatrização e a dor perineal com a utilização das técnicas de sutura contínua e separada em mulheres com parto normal. Realizou-se estudo controlado aleatório, em centro de parto normal, em Itapecerica da Serra, São Paulo. Participaram 61 mulheres com episiotomia ou rotura perineal de segundo grau, alocadas em dois grupos, segundo a técnica de sutura contínua $(n=31)$ ou separada $(n=30)$. Os principais desfechos avaliados foram edema, equimose, hiperemia, secreção, deiscência, fibrose, freqüência e magnitude da dor (avaliada pela escala numérica de 1 a 10). Os dados foram coletados na internação e após a alta (quatro e 41 dias pós-parto). A cicatrização foi por primeira intenção em 100\% dos casos, nas duas técnicas de sutura. Não houve diferença estatisticamente significante para a ocorrência de morbidades, exceto na dor perineal à palpação, com quatro dias de pós-parto, que foi mais freqüente entre as mulheres com sutura separada.

DESCRITORES: parto; períneo; dor; técnicas de sutura; enfermagem obstétrica; ensaios clínicos

${ }^{1}$ RN, M.Sc. in Obstetric and Neonatal Nursing, e-mail: sandra_enf@yahoo.com.br; ${ }^{2}$ PhD in Nursing, Faculty, University of São Paulo, School of Nursing, Brazil e-mail: riesco@usp.br 


\section{INTRODUCTION}

Maternal morbidity caused by perineal trauma in vaginal delivery is a common problem of global occurrence. Annually, 350,000 women in the United Kingdom need postpartum perineal repair. It is estimated that the majority will experience perineal pain and a fifth will have long-term problems, such as dyspareunia ${ }^{(1)}$.

Episiotomy is frequently performed and its incidence is variable, with rates ranging from $9.7 \%$ in Sweden to $100 \%$ in Taiwan, considering both nulliparous and multiparous women. In Latin American hospitals, the rate of episiotomy among nulliparous women varies from $69 \%$ to $96 \%$, with an average of $94 \%$ in the 14 countries studied ${ }^{(2)}$.

In Brazil, these rates exceed $76 \%$, reaching $95.2 \%$ among nulliparous women ${ }^{(3-4)}$. Although episiotomy is a routine intervention in most services, there is a downward tendency due to the advantages of its selective use. Its prevalence diminishes sharply when it is done in view of a protocol of indications. In such cases, the occurrence of perineal lacerations is common and requires suture. In 2001, $26.5 \%$ of women in the Hospital General of Itapecirica da Serra (HGIS) underwent episiotomy after normal delivery ${ }^{(5)}$.

There is little scientific interest in the study of episiotomy indications and complications as well as a lack of research on its surgical repair, denominated perineorrhaphy, despite its high prevalence and potential for morbidities, such as edema, haematoma, pain, infection and dehiscence.

The factors associated with morbidity and related to perineal trauma repair consist in the choice of the suture material, the repair technique and the surgeon's competence, giving rise to research fields in the birth care area ${ }^{(6)}$.

Despite the existence of publication on the types of threads most indicated for perineal suture and on local pain after $\mathrm{it}^{(7-8)}$, studies on the remaining morbidities associated to perineal trauma after normal delivery are rare ${ }^{(1,9-12)}$, especially in Brazilian literature.

A literature review on skin suture techniques in perineal trauma after delivery found only four randomized trials, concluding that the continuous suture technique is associated to lesser pain in the short run. However, authors point to the need for more studies comparing suture techniques ${ }^{(13)}$.
After consideration of this scientifically little explored problem and taking into account the number of women who experience perineal trauma after delivery, the need for repair and local pain, this study was proposed to contribute to the reduction of perineal morbidity related to the suture technique.

The aim was to compare the characteristics of the healing process, the frequency and degree of perineal pain with the use of continuous and interrupted techniques of perineal trauma in women after normal delivery.

\section{METHODS}

A randomized controlled trial (RCT) was adopted to analyze the effect of two different suture techniques of episiotomy and second-degree perineal tear in the healing process and in the occurrence of local pain.

The study was performed in the Birth Center (BC) of the General Hospital of Itapecirica da Serra, in Itapecirica da Serra, SP, Brazil. At the BC, normal deliveries are attended by nurse-midwives, episiotomy is performed based on the institution's protocol and all parturients are accompanied by someone of their choice.

Women who met the following criteria were chosen: presented no leucorrhoea or infectious lesion in the genital area, physiometry, retention of ovular remains or cervical and vaginal cul-de-sac tears during birth; did not undergo blood transfusion; did not use antibiotics, imunossupressors, anti-inflammatories or intimate hygiene products other than soap and water.

The sample was composed of 61 puerperas 31 in the group in which the continuous suture technique was used and 30 in the group in which the interrupted technique was used. Randomization was performed through an electronic table and applied at the moment of delivery to 95 women. A total of 34 women were excluded from the study and replaced by others, according to the randomization table.

The estimator used to determine the sample size (n) was the result of a study on perineal pain in the first ten days after delivery. The average frequency of women with local pain in this study was $51 \%$, varying between $21 \%$ and $63 \%$ between the first and tenth days of puerperium ${ }^{(14)}$. In order to obtain a confidence interval of $95 \%$ in the present study, we estimated that $51 \%$ of the women would experience perineal pain, considering the variation mentioned before. 
The suture was performed with polyglactin 910*, a thread of synthetic origin with tensile strength in vivo of $100 \%$ on the first day, $81 \%$ on the third, $57 \%$ on the fifth, $53 \%$ on the seventh and $0 \%$ after fourteen days. Complete absorption occurs by hydrolysis within approximately 35 days.

For a better result of the suture, "dead space" between the wound edge and exaggerated tension must be avoided, so that an adequate hemostasis of the bleeding vessels in the incision or tear is promoted. Likewise, a minimum of suture levels is recommended, approximating separately the subcutaneous level in case of need. After the suture, hygiene of the perineum must be done with physiological solution.

In both groups, topic polivinil-iodinepirrolidone was used for the antisepsis of the vulvar skin, perineum and internal face of the thighs, and the following surgical tools were used: needle holder and rat tooth surgical tweezers in all suture points.

The interrupted and continuous suture techniques are described below:

Interrupted technique: 1 . Start the suture by the apex of the wound of vaginal mucous membrane with needle $1 / 2$ circle, taper point of four or five centimeters; 2. Fasten the stitch with three knots, with two loops in the first, two inverted loops in the second and a single loop in the third knot, leaving the thread end with approximately one centimeter; 3. Proceed the suture of the mucous membrane with continuous locking stitches up to the hymeneal ring; 4. Fasten the last stitch the same way as the first and cut the thread; 5. In the muscle level, approximate the edges with interrupted stitches, fastening each stitch with three knots in the same way as the previous ones; 6. Approximate the skin edges with interrupted stitches using a $3 / 8$ circle reverse cut needle of three centimeters; 7. Fasten each stitch and cut the thread, leaving the ends with one centimeter.

Continuous technique: 1. and 2. Identical to the technique described above; 3 . Proceed with the suture of the mucous membrane, with continuous non-locking stitches up to the hymeneal ring; 4 . Proceed to the muscle plan with non-locking continuous suture; 5 . At the end of the muscle layer, change the needle to a $3 / 8$ circle reverse cut needle of three centimeters and perform intradermic suture, also continuous, initiating by the inferior part towards the fourchette where the suture is fastened with three knots, fixated by two loops in the first, two inverted loops in the second and a single loop in the third one; 6. Cut the thread, leaving the ends with one centimeter of length.

The perineal suture was performed by one of the researchers and ten nurse-midwives from the BC team, between July 2001 and April 2002. Before starting the research, the nurse-midwives were submitted to theoretical-practical training, with accompanied suture performance and evaluation through the verification of the correct use of the proposed suture techniques.

The data collection was carried out in four steps: the first, denominated Greenberg period, corresponded to the first hour after finishing the perineal suture and was performed by the professional who assisted the delivery. The second step was performed by one of the researchers after consulting the patient's file in order to obtain data related to the parturient period of hospitalization. The third one, denominated first return visit, occurred approximately four days after birth and was carried out by the same researcher or by the outpatient clinic nurse-midwife through an interview with the puerpera, perineal exam and blood sample collection for hemoglobin and hematocrit dosage. The fourth step, denominated second return visit, was also carried out by the same researcher, about 41 days after the delivery, with a new interview and perineal exam. The first and second return visits occurred at the outpatient clinic of the HGIS or at the women's home, when the puerperal woman did not return on the scheduled date.

The independent variables were the continuous and interrupted perineal suture techniques. The dependent variables were: perineal healing process (edema, ecchymosis, hyperemia, secretion, dehiscence and fibrosis); perineal hygiene; suture conditions; frequency and degree of spontaneous perineal pain, and pain due to palpation, to sitting, walking, urinating, evacuating, sexual activity and use of analgesics.

For the signs indicative of healing, swollen perineum (edema), altered skin color (ecchymosis or hyperemia), indication of secretion in the suture

* Kit Vicryl of rapid absorption Ethicon ${ }^{\circledR}$ 
site, separated suture edges in any of the levels (dehiscence) and engorgement of the cicatricial line (fibrosis) were considered. Perineal hygiene was considered adequate when the perineum had no accumulated dirt and inadequate when there was accumulated dirt or bad odor not attributed to the infectious process. In the evaluation of suture conditions, the categories considered were: preserved, partially unfastened or totally unfastened.

When the puerpera reported painful sensation, in the first, third and fourth steps of the study, according to the description above, the degree of pain was evaluated according to a numerical scale from 1 to 10,1 indicating the lowest degree and 10 the highest. The use of analgesics distinguished the use of pain relief medication from hospitalization until the second return visit.

The other variables analyzed were: maternal characteristics (age; vaginal deliveries and previous perineal scar; hematological conditions in the first return visit); perineal suture characteristics (type of trauma; professional who performed it and duration of suture; sutured layers, hemostasis method and bleeding after the suture); characteristics of the newborn (gestational age; vitality; weight).

The SPSS program was used for statistical analysis. Central tendency and dispersion measures were computed for descriptive analysis of the quantitative continuous variables, and absolute and relative frequencies were computed for the qualitative variables. Chi-square $\left(\chi^{2}\right)$ and Fisher's exact tests were used for inferential analysis. A $5 \%$ significance level was considered ( $p$-value=0.05).

The project was approved by the institution's Research Ethics Committee and the women's participation was voluntary after free and informed consent. The participation of midwives in the data collection was also voluntary.

\section{RESULTS}

A total of 96 women who met the inclusion criteria were selected for the research, 95 were allocated in the study groups and $n$ was 61 . The results of 31 women with continuous suture and 30 with interrupted suture were analyzed (Figure 1).

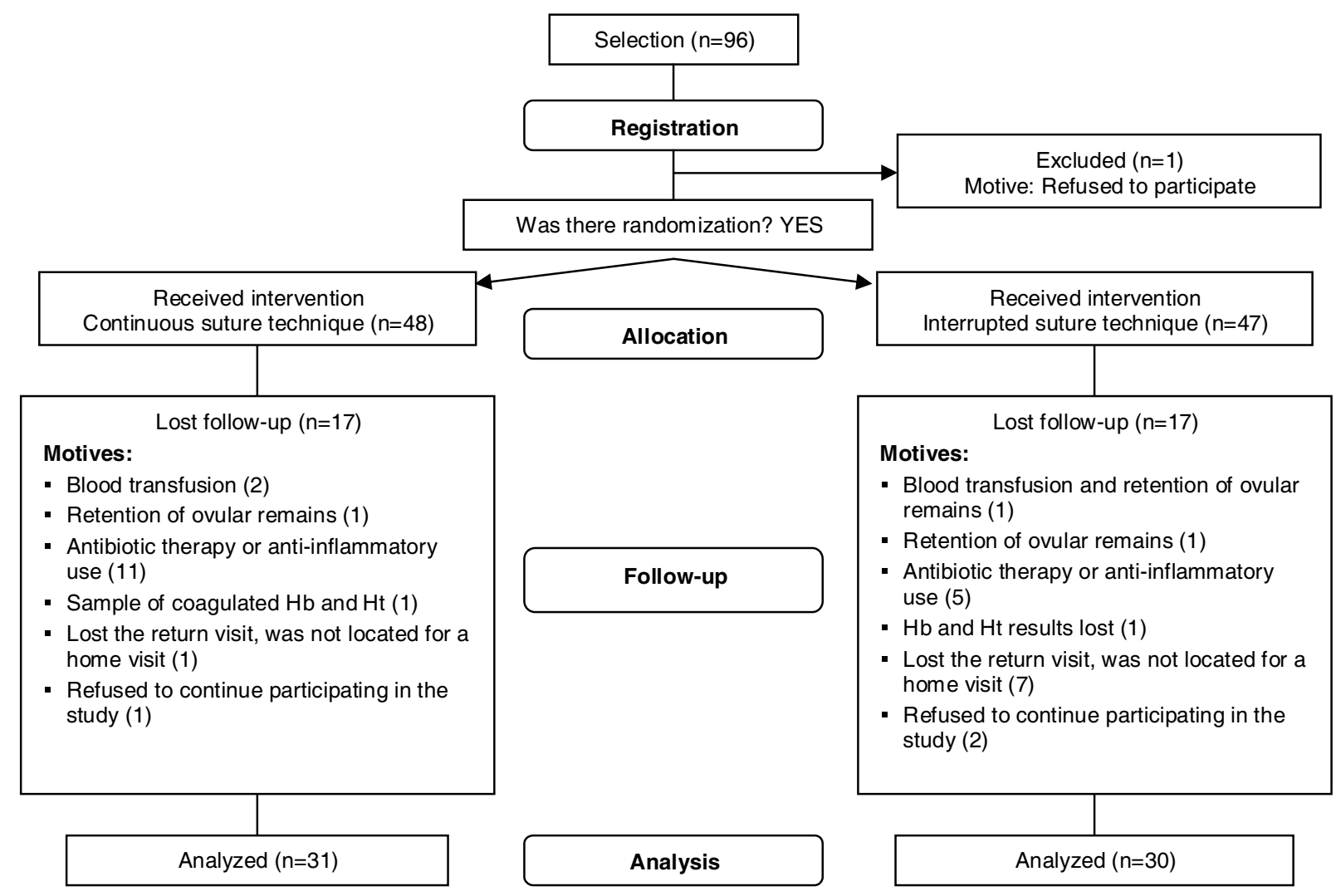

Figure 1 - Fluxogram of participants in the study, from June 2001 to April 2002 
The results regarding maternal conditions and characteristics of perineal suture are presented in Tables 1 and 2, respectively.

Table 1 - Maternal conditions according to the suture technique

\begin{tabular}{lccc}
\hline \multicolumn{1}{c}{ Maternal Condition } & \multicolumn{2}{c}{ Suture Technique } \\
& $\begin{array}{c}\text { Continuous } \\
\mathbf{n}=\mathbf{3 1}(\%)\end{array}$ & $\begin{array}{c}\text { Interrupted } \\
\mathbf{n}=\mathbf{3 0}(\%)\end{array}$ \\
\hline Age (years) $\quad$ Average (s.d.) & $24.2(5.3)$ & $24.2(6,8)$ \\
Hemoglobin (g/dL) & Average (s.d.) & $11.3(1.4)$ & $11.0(1,3)$ \\
Hematocrit (mL/dL) Average (s.d.) & $34.2(3.9)$ & $33.3(4,1)$ \\
Previous vaginal delivery & $16(51.6)$ & $15(50.0)$ \\
Previous perineal scar & $12(38.7)$ & $15(50.0)$ \\
\hline
\end{tabular}

Table 2 - Characteristics of perineal suture according to technique and suture

\begin{tabular}{|c|c|c|c|}
\hline & & \multicolumn{2}{|c|}{ Suture technique } \\
\hline \multicolumn{2}{|c|}{ Characteristics } & Continuous & Interrupted \\
\hline \multirow[t]{2}{*}{ Perineal trauma } & Episiotomy & $15(48.4)$ & $17(56.7)$ \\
\hline & $2^{\text {nd }}$ degree tear & $16(51.6)$ & $13(43.3)$ \\
\hline \multirow[t]{2}{*}{ Nurse-midwife } & BC's team & $12(38.7)$ & $21(70)$ \\
\hline & Researcher & 19 (61.3) & $9(30)$ \\
\hline Suture duration (min) & Average (s.e.) & $16.8(6.2)$ & $21.4(9.5)$ \\
\hline \multirow[t]{3}{*}{ Hemostatic method } & Vessel ligation & $4(66.7)$ & $5(50)$ \\
\hline & Manual pressure & $1(16.7)$ & $4(40)$ \\
\hline & Ligation+pressure & $1(16.7)$ & $1(10)$ \\
\hline \multirow[t]{2}{*}{ Muscle layers } & One & $25(80.6)$ & $12(40)$ \\
\hline & Two or more & $6(19.4)$ & $18(60)$ \\
\hline \multicolumn{2}{|l|}{ Subcutaneous suture } & $11(35.5)$ & $17(56.7)$ \\
\hline \multicolumn{2}{|l|}{ Bleeding after suture } & $3(9.7)$ & $6(20)$ \\
\hline
\end{tabular}

Tables 3 and 4 show the results regarding healing, frequency and degree of perineal pain in each of the study steps. Healing occurred by first intention in $100 \%$ of cases, with both suture techniques.

The median of the numerical scale from 1 to 10 was considered for the degree of spontaneous pain and palpation pain, according to the description provided in the Methods section.

Table 3 - Characteristics of perineal healing according to suture technique

\begin{tabular}{|c|c|c|c|c|}
\hline \multirow[b]{2}{*}{ Stage } & \multirow[b]{2}{*}{ Characteristics } & \multicolumn{2}{|c|}{ Suture technique } & \multirow[b]{2}{*}{ p-value } \\
\hline & & $\begin{array}{c}\text { Continuous } \\
n=31(\%)\end{array}$ & $\begin{array}{c}\text { Interrupted } \\
n=30(\%)\end{array}$ & \\
\hline Greenberg & Edema & $14(45.2)$ & $12(40.0)$ & $0.684^{*}$ \\
\hline \multirow[t]{3}{*}{ Hospitalization } & Edema & $8(25.8)$ & $8(26.7)$ & $0.939^{*}$ \\
\hline & Ecchymosis & $1(3.2)$ & $1(3.3)$ & $0.999^{\star \star}$ \\
\hline & Hyperemia & $2(6.5)$ & $2(6.7)$ & $0.999^{\star \star}$ \\
\hline \multirow[t]{5}{*}{ 1st return visit } & Edema & $1(3.2)$ & $6(20.0)$ & $0.053^{\star \star}$ \\
\hline & Ecchymosis & $3(9.7)$ & $2(6.7)$ & $0.999^{\star *}$ \\
\hline & Hyperemia & $2(6.5)$ & $1(3.3)$ & $0.999^{\star \star}$ \\
\hline & Adequate hygiene & $31(100)$ & 25 (83.3) & $0.024^{\star \star}$ \\
\hline & Presenved suture & 31 (100) & $27(90.0)$ & $0.354^{\star \star}$ \\
\hline 2nd return visit & Cicatricial fibrosis & $11(35.5)$ & $14(46.7)$ & $0.375^{\star}$ \\
\hline
\end{tabular}

$* \chi^{2}$ test

** Fisher's exact test
Table 4 - Frequency and degree of perineal pain according to suture technique

\begin{tabular}{|c|c|c|c|c|}
\hline \multirow[b]{2}{*}{ Stage } & \multirow[b]{2}{*}{ Perineal pain } & \multicolumn{2}{|c|}{ Suture technique } & \multirow[b]{2}{*}{ p-value } \\
\hline & & $\begin{array}{c}\text { Continuous } \\
n=31(\%)\end{array}$ & $\begin{array}{c}\text { Interrupted } \\
n=30(\%)\end{array}$ & \\
\hline Greenberg & Spontaneous [Med] & $3(9.7)[2]$ & $3(10.0)[3]$ & $0.999^{\star}$ \\
\hline Hospitalization & Analgesic use & $18(58.1)$ & 19 (63.3) & $0.674^{\star \star}$ \\
\hline \multirow[t]{7}{*}{1 st return } & Spontaneous [Med] & $15(48.4)[5]$ & $18(60.0)[5]$ & $0.323^{\star *}$ \\
\hline & Palpation [Med] & 20 (64.5) [5] & $27(90.0)[5]$ & $0.018^{\star \star}$ \\
\hline & Sitting & $14(45.2)$ & $20(66.7)$ & $0.091^{\star *}$ \\
\hline & Walking & $4(12.9)$ & $6(20.0)$ & $0.508^{*}$ \\
\hline & Urinating & $4(12.9)$ & $5(16.7)$ & $0.731^{*}$ \\
\hline & Evacuating & $6(19.4)$ & $1(3.3)$ & $0.104^{*}$ \\
\hline & Analgesic use & $9(29.0)$ & $11(36.7)$ & $0.525^{\star *}$ \\
\hline \multirow[t]{6}{*}{ 2nd return } & Palpation [Med] & $4(12.9)[4]$ & 7 (23.3) [3] & $0.289^{\star \star}$ \\
\hline & Sitting & - & $2(6.7)$ & $0.238^{*}$ \\
\hline & Evacuating & - & $1(3.3)$ & $0.492^{*}$ \\
\hline & Analgesic use & 19 (61.3) & $17(56.7)$ & $0.714^{*}$ \\
\hline & Sexual activity & $12(37.8)$ & $11(36.7)$ & $0.869^{*}$ \\
\hline & Dyspareunia [Med] & $5(41.7)[5]$ & $5(45.5)[7]$ & $0.999^{\star}$ \\
\hline
\end{tabular}

* Fisher's exact test

$* * \chi^{2}$ test

According to inferential analysis, there was a higher frequency of adequate perineal hygiene and lower frequency of perineal palpation pain with continuous suture in the first return visit, with statistically significant association for both variables (Tables 3 and 4). The results showed no statistically significant differences between the two perineal suture techniques for the other variables analyzed.

All newborns presented Apgar scores $\geq 9$ at the fifth minute of life; $98.4 \%$ were full-term according to gestational age based on Capurro's method. Their weight varied between 2,140 and 4,180 grams, with an average of $3,274.8$.

\section{DISCUSSION}

The local inflammatory signs and symptoms such as edema, pain, redness and heat are expected in the initial phase of the healing process and subside as local reactions and absorption of the suture material evolve. However, perineal trauma morbidities, such as haematoma, ecchymosis, infection and dehiscence, hinder complete maternal recovery. The puerpera's characteristics and general conditions, such as age, protein deficiency, deficit of tissue oxygen and drugs action, influence the time and quality of healing ${ }^{(15)}$. The variables that can affect the healing process, not controlled by the study inclusion criteria, were analyzed and indicated sample homogeneity (Table 1 ).

The type of trauma, manipulation of the site and closeness of tissue levels in the suture are 
important aspects for the reduction of pain and the good evolution of the healing process. Studies indicate better results in cases of spontaneous laceration when compared to episitomy, with less suture layers ${ }^{(16)}$.

The technical details of the suture appoint the advantages of continuous suture (Table 2). In this technique, large layers of muscle tissue are seized with approximation in one single level. The suture depends on the subcutaneous anatomic characteristics in the perineum; when this level is slim, its approximation occurs with the skin suture.

Although the application of some hemostasis method produces greater manipulation, it might be necessary because the perineal trauma bleeding is a morbidity factor. Bleeding after the suture, hardly frequent with continuous suture, indicates the hemostatic effect of this technique. The partially unfastened suture in the skin, verified in three cases with interrupted suture during the first return visit, can be attributed to the lack of an inverted slipknot in all knots. After these occurrences, the importance of inverting the slipknot with the use of a more smooth and slippery suture thread, like the one adopted in this study, was stressed among the nurse-midwives and the problem did not happen again (Table 2).

Despite the benefits reported in literature, including diminished pain and increased mobility of women submitted to continuous suture of the perineal trauma(13), professionals admit experiencing some personal uneasiness when exposed to the nontraditional suture technique for the first time ${ }^{(1,11)}$. In this study, despite the training provided, some nurses initially reported being afraid to perform continuous suture. Due to this fact, the majority of sutures with this technique was performed by the researcher (Table $2)$. This aspect, which can constitute bias, was appointed in other studies, suggesting that the interrupted technique is more commonly taught and easier to be performed by inexperienced professionals $^{(1,6,13)}$.

The delay in trauma repair was smaller with the continuous technique, with the advantage that, the lesser time spent in the suture, the smaller the risk of infection and the puerpera's discomfort (Table 2).

The development of the healing process and the result observed in the second return visit postpartum did not indicate statistically significant differences between continuous and interrupted perineal suture techniques. Precocious edema is more frequent in the Greenberg period and can be associated to manipulation during birth and to the anesthetics accumulated in the tissue. Its persistence can be attributed to local inflammatory reaction and to the quantity of material used in trauma repair (Table 3). It is important to consider that polyglactin 910 is a thread with short exudative phase, early proliferative phase and absorption by minimal tissue reaction $^{(17)}$

Perineal ecchymosis, resulting from blood outflow to interstitial space, was more evident in the first return visit, without statistically significant differences between groups. This sign tends to resolve spontaneously by re-absorption without further consequences for good tissue healing. It is worth mentioning that, immediately after the suture, local bleeding was present in nine cases.

Report of comparison of the esthetic results of the perineal suture with the traditional and continuous techniques, six weeks after delivery, indicates that scars were totally indistinguishable between both suture types, though skin closeness in the first technique is done by direct approximation of the edges while, in the second, tissue edges are incompletely united by a deeper intradermic suture. In view of the results of eight years of clinical practice with continuous suture, in which there was no infection related to suture, the predisposition to perineal wound infection with the use of this technique was discarded ${ }^{(11)}$. Likewise, none of the puerperas presented infection of the perineal wound in the present study, although there were some cases of hyperemia. In all cases, healing occurred in the first intention.

Local hygiene is important for good healing and lochia is a means of culture for bacteria. The women in this study were oriented to keep perineal hygiene with water and soap. However, during the first return visit, a statistically significant difference was observed between the two groups $(p=0.024)$, with good conditions of perineal hygiene in all women with continuous suture. The knot on the skin left by the interrupted suture causes discomfort and fear of accidentally unfastening the suture, which can favor accumulation of dirt, predisposing to infection.

As presented in the Introduction, there is little research on perineal morbidity related to the perineal trauma suture technique during delivery. The clinical trials found in literature mainly analyze spontaneous pain in the short run (frequency and analgesics use), the need for re-suture and dyspareunia as outcomes $^{(1,10,12-13)}$. 
The $\mathrm{RCT}^{(1)}$ performed with 1,542 women in England indicated that continuous suture reduces perineal pain in one out of six women, on the tenth day after delivery. The benefits of this technique were also evidenced in other periods of the puerperium ( 2 days, 3 and 12 months after delivery), with lesser pain when walking, sitting, urinating and evacuating. Only in the case of complaints related to dyspareunia did the results of both continuous and interrupted techniques show no differences. These findings are similar to those obtained in the systematic review previously performed with four $\mathrm{RCT}^{(13)}$.

In the present study, the higher frequency of perineal pain with median degree 5 on a scale from 1 to 10 was registered during the first return visit spontaneous pain, palpation pain and pain when sitting. Palpation pain was more frequent among puerperas with interrupted suture technique and was the only result with statistically significant difference $(p=0.018)$. Dyspareunia was reported as pain of higher degree among the same group of women, with median 7 (Table 4).

We consider the main limitation of this study to be the lack of concealing, which cannot be performed for obvious reasons. However, the participation of more than one observer in outcome assessment might control the occurrence of measuring bias.

\section{CONCLUSION}

The continuous and interrupted perineal suture techniques with Vicryl of rapid absorption

\section{REFERENCES}

1. Kettle C, Hills RK, Jones P, Darby L, Gray R, Johanson R. Continuous versus interrupted repair with standard or rapidly absorbed sutures after spontaneous vaginal birth: a randomised controlled trial. Lancet 2002; 359:2217-23.

2. Graham ID, Carroli G, Davies C, Medves JM. Episiotomy rates around the world: an update. Birth 2005; 32(3):21923.

3. Oliveira SMJV, Miquilini EC. Freqüência e critérios para indicar a episiotomia. Rev Esc Enferm USP 2005; 39(3):28895.

4. Davim RMB, Enders BC, Reis MN. Estudo retrospectivo quanto à prática da episiotomia e a ocorrência de lacerações perineais em uma maternidades-escola. Nursing 2003; 62(6)38-42.

5. Schneck CA, Riesco MLG. Intervenções no parto de mulheres atendidas em um centro de parto normal intrahospitalar. Rev Min Enf 2006; 10(3):240-6. (polyglactin 910) showed to be equally adequate and safe for the repair of perineal trauma and local healing.

Continuous suture was less related to perineum pain due to palpation four days after delivery, as well as activities such as sitting, walking, urinating and evacuating during the puerperium. At 41 days after delivery, none of the puerperas with continuous suture reported pain related to these activities. There was no statistically significant difference for the occurrence of other morbidities. Healing occurred by first intention in $100 \%$ of cases in the two suture techniques. The favorable results obtained can also be attributed to the good suture technique performed by the BC's nurse-midwives, with both methods studied.

We consider that the work involving perineal trauma care, techniques and suture threads must be stimulated among health professionals. Additionally, the knowledge available in other areas, such as surgery, must also be used for the improvement of current practice.

\section{ACKNOWLEDGEMENTS}

To the State of São Paulo Research Foundation for financial support and to EthiconJonhson\&Jonhson, represented by Anita N. Ribeiro, for the incentive and concession of the suture thread.

6. Grant A. Commentary: repair of episiotomies and perineal tears. BJOG 1986; 93(5):417-9.

7. Greenberg JA, Lieberman E, Cohen AP, Ecker JL. Randomized comparison of chromic versus fast-absorbing polyglactin 910 for postpartum perineal repair. Obstet Gynecol 2004; 103(6):1308-13.

8. Leroux N, N, Bujold E. Impact of chromic catgut versus polyglactin 910 versus fast-absorbing polyglactin 910 sutures for perineal repair: a randomized, controlled trial. Am J Obstet Gynecol 2006; 194(6):1585-90

9. Grant A, Gordon B, Mackrodat C, Fern E, Truesdale A, Ayres S. The Ipswich childbirth study: one year follow up of alternative methods used in perineal repair. BJOG 2001; 108(1):34-40.

10. Mahomed K, James D, Grant A, Ashurst H. The Southmead perineal suture study: a randomized comparison of suture materials and suturing techniques for repair of perineal trauma. BJOG 1989; 96(11):1272-80

11. Fleming N. Can the suturing method make a difference in postpartum perineal pain? J Nurse Midwifery 1990; 35(1):19-25. 
12. Isager-Sally L, Legarth J, Jacobsen B, Bostofte E. Episiotomy repair - immediate and long-term sequelae. A prospective randomized study of three different methods of repair. BJOG 1986; 93(5):420-5.

13. Kettle C, Johanson RB. Continuous versus interrupted sutures for perineal repair (Cochrane Review). In: The Cochrane Library, Issue 3, 2007. Oxford: Update Software. 14. Alexandre CW, Kimura AF, Tsunechiro MA, Oliveira SMJV. A interferência da dor nas atividades e necessidades da puérpera. Nursing 2006; 93(9):664-8.

15. Bevilacqua RG, Chapchap P, Almeida CG. Cicatrização. In: Algöwer M. Manual de cirurgia. $4^{a}$ ed. São Paulo: EPU; 1988. p.1-20.

16. Myers-Helfgott MG, Helfgott A. Routine use of episiotomy in modern obstetrics. Obstet Gynecol Clin North Am 1999; 26(2):305-25.

17. Carvalho PSP, Okamoto T, Carvalho ACP, Rodrigues SO. Estudo comparativo em ratos da inflamação provocada por três fios de sutura absorvíveis. Rev Ciênc Bioméd 1985; $6: 31-41$. 